Федоренко Лариса Олександрівна

кандидат філологічних наук, доцент

Житомирський державний університет імені Івана Франка, м. Житомир, Україна

ORCID ID 0000-0001-5278-7034

fvm34@outlook.com

\title{
ВИКОРИСТАННЯ ВЕБ-КВЕСТІВ У НАВЧАННІ НІМЕЦЬКОЇ МОВИ В ЗАКЛАДАХ ВИЩОЇ ОСВІТИ
}

\begin{abstract}
Анотація. У статті розглянуто та описано використання веб-квестів як сервісу Веб 2.0 на заняттях 3 іноземної мови. Проаналізовано основні етапи роботи над веб-квестом: введення теми, постановка завдання, представлення допоміжних матеріалів, виконання завдання, презентація, обговорення та оцінювання презентацій. Виділено найважливіші ознаки сервісу: доступність, легкість у використанні, можливість комунікації та співпраці, зокрема віддаленої, залучення колективного «розуму», можливість створення і зберігання інформації, візуалізації навчального змісту, створення умов для самоосвіти і саморозвитку студентів. В основі дослідження лежать концепції, підходи, принципи та методи нейродидактики. У статті доводиться, що цілеспрямоване використання веб-квестів, як і інших ресурсів Веб 2.0, цілком відповідає сучасним принципам нейродидактики в аспекті ефективності освітнього процесу, зокрема: використання веб-квестів сприяє підвищенню мотивації та інтенсифікації вивчення іноземної мови; надає заняттю інноваційних характеристик, комунікативно-діяльнісного спрямування, а також креативності, пізнавального та ігрового характеру; ефективно підтримує роботу викладача, сприяє результативній самостійній і груповій роботі; відповідає принципам «багатоканального» навчання, до якого залучено велику кількість органів чуття людини; сприяє усуненню мовних та психологічних «бар'єрів»; найчастіше супроводжується позитивними емоціями і показниками навчального успіху, що є передумовами мотивації та ефективної комунікації на заняттях іноземної мови. Використання веб-квестів відповідає також принципу «Learning by Doing» («навчання через практичну діяльність»), відповідно до якого наш головний мозок функціонує у такий спосіб, що ми найкраще сприймаємо та запам'ятовуємо той інформаційний матеріал, який самі опрацьовуємо або виробляємо. Важливим також є врахування індивідуального темпу навчання студентів i можливість залучення всіх навчальних типів відповідно до каналу сприймання інформації: аудитивного, візуального, комунікативного, моторно-кінестетичного.
\end{abstract}

Ключові слова: Веб 2.0; Webquest; веб-квест; інноваційність; нейродидактика; креативність; PowerPoint.

\section{1. ВСТУП}

Постановка проблеми. Нове століття подарувало нам інноваційні технологічні можливості, новітні освітні стандарти і значні зміни в підходах і принципах організації занять з іноземної мови. Невід’ємною частиною освітнього простору стала мережа Інтернет. Які ресурси всесвітньої мережі є ефективними і доцільними на заняттях іноземної мови $\epsilon$ проблемним питанням цієї розвідки. У статті ми зосередимось на сучасних сервісах Веб 2.0, оскільки саме вони видаються нам результативними та продуктивними у формуванні комунікативної іншомовної компетентності та підвищенні мотивації до вивчення іноземних мов.

Веб 2.0 вживається на позначення інтерактивних та колаборативних ресурсів мережі Інтернет, за яких користувач не лише пасивно споживає зміст сервісу, а й виступає безпосереднім постачальником, просьюмером інформації. На відміну від сервісу Веб 1.0, який давав можливість лише певним організаціям створювати та поширювати контент у всесвітній мережі, а численні користувачі могли лише отримувати готовий зміст, користувачі Веб 2.0 (просьюмери) створюють, опрацьовують і поширюють у кількісний та якісний спосіб інформацію, користуючись інтерактивними технологіями. 
До основних характеристик Веб 2.0, на думку винахідника терміна Тіма О’Рейлі [1], належать:

- можливість комунікації та співпраці користувачів;

- зручність і легкість у використанні;

- залучення колективного «розуму».

Адже чим більше просьюмерів працює над певною інформацією, тим важливішим і ціннішим стає Веб 2.0-продукт.

Переважна кількість Веб 2.0-технологій не потребує спеціальної освіти і може використовуватися без особливих зусиль (наприклад, створення Wordle, блогів, подкастів, Mindmap).

Метою статті є аналіз ресурсу Webquest як сервісу Веб 2.0, висвітлення особливостей його використання на заняттях іноземної мови в закладах вищої освіти.

Аналіз останніх досліджень і публікацій. Дослідження базується на концепціях, підходах, принципах та методах нейродидактики, зокрема на результатах науковопрактичних досліджень Манфреда Шпітцера (нар. 1958) - німецького психіатра, психолога, професора, дослідника головного мозку, автора праць «Навчання: винайдення зрозумілого» (Lernen - Die Entdeckung des Selbsverständlichen) [2], «Навчання: дослідження мозку та школа життя» (Lernen - Gehirnforschung und die Schule des Lebens) [3], «Медицина для освіти: вихід із кризи» (Medizin für die Bildung - Ein Weg aus der Krise) [4], «Школа та іiі обов’язки сьогодні» (Schule, und was sie heute leisten sollte) та ін.

Суттєвий внесок в досвід використання веб-квестів як сервісу Веб 2.0 зробили дослідники Ніколаєва Н. В. (дослідження веб-квесту як методу і засобу формування навичок інформаційної діяльності студентів та учнів), Романцова Ю.В.(дослідження веб-квесту як способу активації навчальної діяльності учнів та студентів), Андрєєв М. В. (використання веб-квест-технологій в організації самостійної діяльності студентів), Биховський Я. С. (діяльнісний підхід в освітньому веб-квесті), Іць С. В. (медіаосвітні веб-квести як засіб формування критичного мислення студентів на заняттях іноземної мови), Фенчук О. О (вебквест як інноваційна проектна методика навчання іноземної мови), Кадемія М. Ю., Гуревич Р. С. і Шестопалюк О. В. (методика застосування веб-квестів у різних країнах, проектна діяльність студентів і учнів, методика оцінювання веб-квестів тощо) та інші.

\section{2. ТЕОРЕТИЧНІ ОСНОВИ ДОСЛІДЖЕННЯ}

Сучасні дослідження головного мозку вказують:

- кожен головний мозок є унікальним, звідси: різні учні мають різний рівень засвоєння матеріалу при однаковому викладанні матеріалу;

- спроможність головного мозку кожної людини (особливо в юному віці) $\epsilon$ надзвичайно потужною. Проте завжди є ризик його «блокади» через демотивацію, що спричинена нудним зубрінням, постійними навчальними невдачами, деконструктивною критикою, приниженням, публічним висміюванням тощо);

- знання не можна «передати», вони «продукуються» у головному мозку в процесі навчання [3].

Виходячи $з$ принципів нейродидактики та особливостей головного мозку людини, освітній процес слід організовувати різноманітно, оптимально варіюючи складний теоретичний матеріал 3 практичними завданнями ${ }^{1}$. Навчання має приносити задоволення та, перш за все, орієнтуватися на актуальні інтереси й потреби учнів чи студентів. Варто надавати перевагу коротшим, але частішим навчальним вправам, доцільно варіювати повторення та нові завдання.

\footnotetext{
${ }^{1}$ Під «оптимальністю» в даному контексті ми розуміємо найбільш доцільний та відповідний певному завданню, умовам, віковій категорії принцип розподілу навчального матеріалу.
} 
До основних положень нейродидактики, які необхідно враховувати в освітньому процесі, належать також і такі:

1. Навчання $\epsilon$ процесом накопичувальним, тому варто спиратися і враховувати вихідні та попередні знання і досвід студентів з певної теми тощо.

2. Доведена ефективність «багатоканального» навчання, до якого залучено велику кількість органів чуття: зір, слух, нюх, смак, дотик, відчуття положення тіла в просторі.

3. Ефективне навчання потребує регулярності, систематичності, великої кількості практичних вправ та повторення.

4. Освітній процес відбувається ефективніше, якщо супроводжується позитивними емоціями i показниками успіху. Негативні емоції, навпаки, перешкоджають освітньому процесу, уповільнюють навчальні результати, призводять до навчальних «бар'єрів», відчуття апатії та страху.

5. Learning by Doing («навчання через практичну діяльність»): відповідно до особливостей функціонування головного мозку ми найкраще сприймаємо та запам'ятовуємо той навчальний матеріал, який самі опрацьовуємо або виробляємо [2] - [4]. (див. рис. 1).

\begin{tabular}{|ll|}
\hline & Ми вивчаємо і засвоюємо... \\
• & $10 \%$ з того, що читаємо; \\
$\bullet$ & $20 \%$ з того, що чуємо; \\
$\bullet$ & $30 \%$ з того, що бачимо; \\
$\bullet$ & $70 \%$ з того, що говоримо; \\
$\bullet$ & $90 \%$ з того, що ми самі робимо \\
\hline
\end{tabular}

Рис.1 Особливості сприйняття головного мозку

6. Оскільки кожен головний мозок є унікальним, кожен учень має не лише свій індивідуальний темп навчання, а також свій найбільш ефективний канал сприймання інформації. У нейродидактиці відповідно виділяють аудитивний, візуальний, комунікативний, моторно-кінестетичний навчальні типи [5] (див. табл. 1)

Таблиия 1

Класифікація навчальних типів за органами сприймання

\begin{tabular}{|c|c|}
\hline Навчальний тип & $\begin{array}{l}\text { Органи або } \\
\text { спосіб } \\
\text { сприймання } \\
\text { інформації }\end{array}$ \\
\hline $\begin{array}{l}\text { Аудитивний mun } \\
\text { Легко сприймає і запам'ятовує інформацію на слух: усні презентації, } \\
\text { радіорепортажі та ін. Для аудитивного типу корисно озвучувати } \\
\text { письмову інформацію та повторювати її вголос. }\end{array}$ & Слух \\
\hline $\begin{array}{l}\text { Візуальний тип } \\
\text { Найкраще сприймає інформацію оптично: читаючи тексти, які містять } \\
\text { візуальну опору (картинки, графіки, таблиці, схеми), переглядаючи } \\
\text { фільми. Для візуального типу доцільно фіксувати або ілюструвати певну } \\
\text { інформацію схематично, виділяти найсуттєвіше в тексті маркером тощо. }\end{array}$ & 3ip \\
\hline $\begin{array}{l}\text { Комунікативний тип } \\
\text { Найкращий спосіб навчання для комунікативного типу полягає у } \\
\text { спілкуванні, участі в дискусіях, різного роду обговоренні інформації. } \\
\text { Доцільними формами організації навчальної діяльності є робота в парі, } \\
\text { групова робота. }\end{array}$ & Комунікація \\
\hline
\end{tabular}




\section{Моторно-кінестетичний тип}

Такий тип найкраще сприймає інформацію через дотик моторику та рух. Навчальна діяльність відбувається за допомогою великої кількості практичних вправ, експериментів, дослідницької роботи тощо. Врахування моторно-кінестетичний навчального типу відповідає

Дотик, рух, практичні вправи психолого-педагогічному принципу learning by doing.

Врахування індивідуальності сприйняття кожного учня є необхідною передумовою успішності навчальної групи загалом.

\section{3. РЕЗУЛЬТАТИ ДОСЛІДЖЕННЯ}

Webquest (режим доступу до сервісу: http://www.webquests.ch/) - це технологія організації проблемного завдання, яке має бути виконане за допомогою пошукової роботи в мережі Інтернет.

Цей сервіс Веб 2.0 передбачає поетапність виконання певних навчальних завдань, має чітко організовану структуру та методи дослідження. На відміну від класичного (фронтального) заняття веб-квест сприяє самостійності студентів, формуванню навичок самостійного вирішення проблемних завдань, а також свідомості та активності студентів у навчально-виховному процесі.

Як засіб навчання веб-квест може складається з таких етапів:

\section{1) Введення теми, вступне роз'яснення}

На початковому етапі викладач має запропонувати тему та окреслити проблематику завдання. Рекомендується обирати для студентів конкретну автентичну проблемну ситуацію, яку можна означити за допомогою вступної бесіди чи невеликої розповіді, відео-, аудіоінформації, які б мотивували їх до виконання завдання та відповідали колу їхніх інтересів.

\section{2) Постановка завдання}

Завдання повинне мати проблемно-пошуковий характер i не зводитися до елементарного «знайди і скопіюй правильну відповідь». Перед виконанням веб-квесту можливе також обговорення проблемного питання з класом чи академічною групою, а також його модифікація, конкретизація чи розширення. Ефективними, на наш погляд, $€$ використання диференційованих завдань та відповідний поділ академічної групи на невеликі робочі групи. Важливо також визначити критерії, за якими буде оцінюватися результат роботи.

\section{3) Представлення допоміжних матеріалів}

Для виконання завдання студенти отримують від викладача перелік Інтернет-ресурсів у формі посилань на веб-сторінки, які слугують певним орієнтиром у веб-квесті. Проте не лише Інтернет має стати єдиним джерелом та ключем до розв'язання проблеми. Варто рекомендувати у веб-квесті також посібники, словники, газетні статті тощо. Окрім того, при виконанні завдання студенти можуть звертатися до експертів, фахівців, «свідків», 3 якими можна спілкуватися безпосередньо або за допомогою соціальних мереж чи електронного листування.

\section{4) Виконання завдання}

Студенти виконують проблемне завдання, керуючись планом та використовуючи рекомендовані матеріали.

\section{5) Презентація}

Кожна група представляє своє завдання та його розв'язання у вигляді презентації (пропонуємо використання додатку PowerPoint, а також сервісів Voicethread, Padlet, Spicynodes / Mindmap та інших).

\section{6) Обговорення та оцінювання презентацій}


На заключному етапі викладач разом з групою обговорює представлені веб-квести, аналізує результат за «критеріями оцінювання», що були визначені на етапі постановки завдання.

Наведемо приклад роботи 3 веб-квестом, який використовувався на заняттях 3 німецької мови як другої іноземної в Навчально-науковому інституті іноземної філології Житомирського державного університету імені Івана Франка при вивченні теми «Визначні місця Мюнхена».

На поданих нижче рисунках представлена покрокова інструкція 3 розробленими завданнями для опрацювання краєзнавчої теми в групі у вигляді PowerPoint-презентації німецькою мовою (див. рис. 2-8).

\title{
WebQuest
}

\section{München: Frauenkirche}

\author{
Ein Unterrichtsprojekt \\ mit Computer und Internet
}

Klicken Sie nun bitte weiter auf

Einführung.

Einführung Aufgabe Schritte Materialien Rückblick Präsentation

Pис. 2. Використання сервісу Webquеst при вивченні краєзнавчої теми „,Mӥnchen:

Frauenkirche“

На початковому етапі роботи над веб-квестом студентам пропонувалася коротка ознайомча інформація з зображенням про собор Фрауенкірхе в Мюнхені. Викладач поставив також кілька запитань, які, з одного боку, активізували фонові знання студентів, а 3 іншого, викликали інтерес до теми і майбутнього завдання (див. рис. 3)

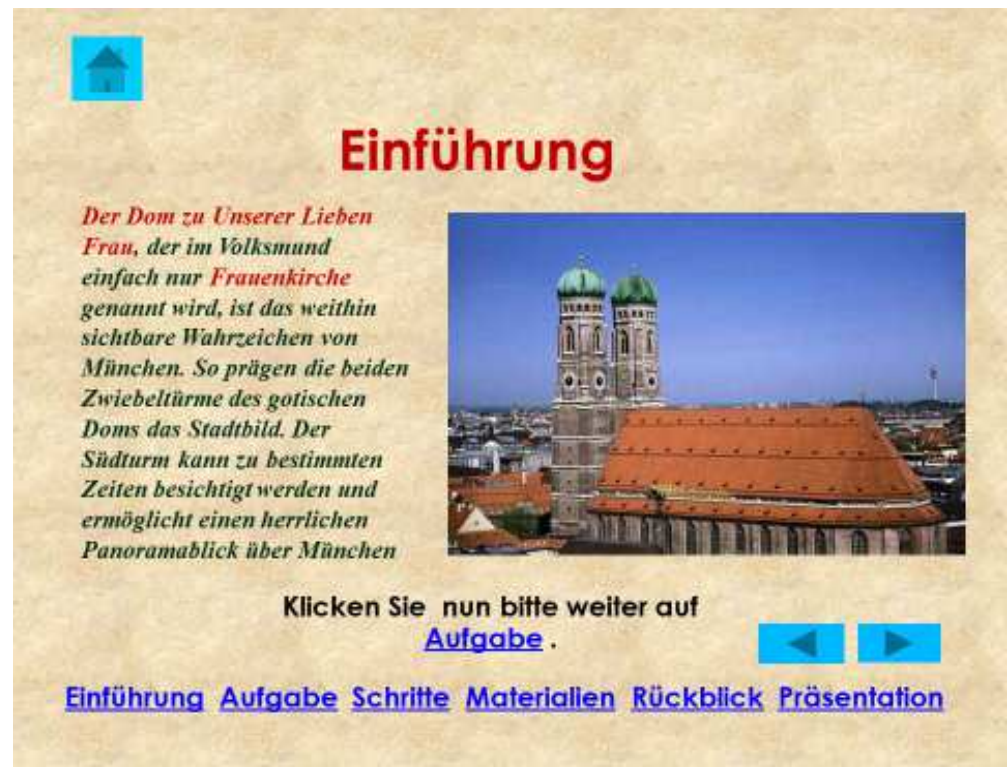

Рис. 3. Введення теми. Загальна інформачія щуодо об'єкту веб-квесту 
Варто зазначити, що для навчання за запропонованою методикою у студентів мають бути попередньо сформовані такі інформаційно-пошукові навички, як вміння користуватися мережею Інтернет; знаходити необхідну інформацію і виключати другорядну, неважливу; вміння копіювати, зберігати, критично осмислювати, структурувати, систематизувати, у разі потреби адаптувати (скорочувати, модифікувати) матеріал, запропонований у мережі Інтернет.

На подальших етапах були сформульовані запитання для пошукової роботи (див. рис. 4), була надана покрокова інструкція з виконання веб-квесту, поради щодо організації групової роботи, раціонального розподілу часу (див. рис. 5), а також перелік матеріалів, Інтернет-ресурсів, рекомендованих для розв'язання веб-квесту (див. рис. 6).

\section{Aufgabe}

1. Man spricht von der Alten und Neuen Kirche. Warum? Rekapitulieren Sie mithilfe von Internetlinks die Geschichte der Fravenkirche.

2. Welche Legenden sind damit verbunden?

3. Was ist das Besondere an der Fravenkirche? Denken Sie an den Baustil.

Klicken Sie nun bitte weiter auf $\underline{\text { schritte. }}$. Dort können Sie nachlesen, wie Sie vorgehen müssen, um Ihre Aufgabe zu bearbeiten.

Einführung Aufgabe Schritte Materiallen Rückblick Präsentation

Рис. 4. Постановка завдань

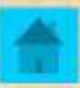

\section{Schritte}

Für diese Schritte haben Sie insgesamt 90 Minuten Zeit.

1. Bilden Sie Gruppen von 3-4 Personen.

2. Jede Gruppe übernimmt eine der Aufgaben.

3. RecherchierenSle im internet. Geeignete

Adressen finden Sie auf der nächsten Selte.

4. Jede Gruppe bespricht dann die Ergebnisse der Recherche.

5. Uberlegen Sie, wie Sie die Ergebnisse präsentieren möchten.

6. Berelten Sle sich auf dle Präsentation vor.

Für jede Präsentation sind 15 Minuten vorgesehen.

Klicken Sie nun bitte weiter auf Materialien.

Einführung Aufgabe Schritte Materialien Rückblick Präsentation

Рис. 5. Покрокова інструкиія з виконання веб-квесту 


\section{Materialien}

Geeignete Web-Seiten für Ihre Recherche.

- wuw.muenchen.de/Tourismus/Sehenswuerdigkeiten

- de.wikipedia.org/wiki/Fravenkirche_(München)

- http://umw.muenchen.de/sehenswuerdigkeiten/orte/120372.htm

- https://www.historisches-lexikon-bayerns.de/Lexikon/Frauenkirche

\section{Klicken Sie nun bitte weiter auf Rückblick.}

\section{Einführung Aufgabe Schritte Materiallen Rückblick Präsentation}

Рис. 6. Перелік матеріалів, рекомендованих для розв'язання веб-квесту

Після виконання веб-квесту і підготовки презентації можливий також етап самоаналізу роботи кожної групи на основі запропонованих критеріїв (див. рис. 7), після чого відбувається презентація результатів і дискусія (див. рис. 8).

\section{Rückblick}

- Wie gut sind Sie mit den Aufgaben zurecht gekommen?

- Wenn es Probleme gab, wie haben Sie diese gelöst?

- Hat Ihre Zeiteinteilung funktioniert?

- Wie gut hat Ihr Teamwork geklappt?

- Zu welchen Themen möchten Sie noch ein WebQuest bearbeiten?

- Was würden Sie beim nächsten Mal genau so oder ganz anders machen?

Klicken Sie nun bitte weiter auf

Präsentation.

Einführung Aufgabe Schritte Materiallen Rückblick Präsentation

Рис. 7. Запитання для самоаналізу 


\section{Präsentation}

Stellen Sie nun die Ergebnisse Ihrer Recherche vor.

- Teilen Sie in der Gruppe auf, wer welche Ergebnisse präsentiert.

- Sprechen Sie auch über die Erkenntnisse, die Sie durch Ihren Rückblick gewonnen haben.

- Gestalten Sie eine PowerPoint Präsentation

- Versuchen Sie, möglichst frei zu sprechen.

- Sprechen Sie beim Präsentieren laut, deutlich und nicht zu schnell.

- Lassen Sie am Ende der Präsentation ein paar

Minuten Zeit, um mögliche Fragen zu beantworten.

4

Einführung Aufgabe Schritte Materialien Rückblick Präsentation

Рис. 8. Рекомендації щчодо презентаиії результатів веб-квесту

Варто зазначити, що вагомою перевагою сервісу Webquest $\epsilon$ також можливість віддаленої кооперативної роботи учасників. Можна, приміром, працювати над спільним проектом і бути при цьому не в інституті, а вдома, у разі потреби комунікуючи з учасниками в зручному для себе режимі: через відеозв'язок, голосове чи текстове спілкування в мережі Інтернет. Тобто виконавці веб-квесту, працюючи автономно, взаємодіють при цьому один 3 одним, а також з викладачем в індивідуальному темпі та в зручному для себе місці.

Окрім презентації PowerPoint, ефективними та інтерактивними сервісами для презентації веб-квестів є мультимедійні платформи Voicethread (режим доступу до сервісу: https://voicethread.com/), Padlet (режим доступу до сервісу: https://de.padlet.com), Spicynodes / Mindmap (режим доступу до сервісу: http://www.spicynodes.org/).

Voicethread пропонує роботу з аудіо- та відеоматеріалом, дозволяє коментувати зміст у вигляді аудіо- чи відеозапису, створювати колажі з аудіо- та відеоінформацією.

Padlet - це сервіс, за допомогою якого можна створити віртуальну стіну 3 різноманітних мультимедійних даних: текстів, веб-сторінок, аудіо, відео, Інтернет-посилань, картинок тощо.

Spicynodes - це сервіс для лаконічного візуального представлення певної теми, що входить до сервісу Mindmap - великої групи сервісів побудови карт знань (карти думок, ментальних карт). Spicynodes добре підходить для наочного упорядкування в класовій, родовій, типологічній формі певних понять, явищ, поділ їх на категорії. Для цього користувачі сервісу можуть створювати велику кількість розгалужень від понять, термінів тощо і диференціювати їх, використовуючи кольорову палітру ресурсу.

Наш досвід використання інтерактивних сервісів Voicethread, Padlet, Spicynodes / Mindmap на заняттях з німецької мови для студентів ННІ іноземної філології ЖДУ імені Івана Франка дозволив нам дійти висновку, що доцільне їх використання сприяє розвитку навичок говоріння, аудіювання, письма; розвитку креативності, залучення студентів до активної творчої діяльності; розвитку навичок аргументації, висловлювання власної думки в усному та письмовому мовленні; створює умови для формування навичок самоосвіти й саморозвитку; надає комунікативне середовища, в якому студенти розвивають інтерес до вивчення іноземної мови; створює психологічно-комфортні умови для розвитку різних видів мовної та мовленнєвої діяльності.

Загалом у результаті успішного опрацювання запропонованого веб-квесту студенти ЖДУ імені Івана Франка продемонстрували такі вміння та навички: 
Загальні компетентності:

- ефективно планувати роботу в групі, розподіляти завдання між учасниками;

- працювати автономно;

- критично опрацьовувати та використовувати джерела, допоміжний матеріал;

- презентувати результат пошукової роботи в академічній групі;

- за допомогою визначених критеріїв аналізувати і оцінювати власні здобутки. Фахові (іншомовні комунікативні) компетентності:

- розповідати в коротких монологах та в діалогічному мовленні про собор Фрауенкірхе як одне з визначних місць Мюнхена;

- відповідати на запитання, коментарі, вести дискусії, висловлювати конструктивну критику.

Крім того, необхідно відзначити підвищення інтересу студентів до вивчення німецької мови, їхню зацікавленість культурою Німеччини, значне покращення комунікативної спроможності студентів, комунікативно-діяльнісний, інноваційний та ігровий характер занять, а також покращення психологічного клімату на занятті, зняття напруги, стресу при виконанні завдань.

\section{4. ВИСНОВКИ ТА ПЕРСПЕКТИВИ ПОДАЛЬШИХ ДОСЛІДЖЕНЬ}

У статті ми розглянули сервіс Webquest як один з ресурсів Веб 2.0, на прикладі описали його застосування на заняттях іноземної мови.

Як зазначають дослідники 3 теми і як показав наш педагогічний експеримент, до найважливіших характеристик сервісу належать можливість комунікації та співпраці, зокрема віддаленої, залучення колективного «розуму», можливість створення і зберігання інформації, візуалізації навчального змісту, створення умов для самоосвіти і саморозвитку студентів.

Доцільне використання веб-квестів, як і інших ресурсів Веб 2.0, цілком відповідає сучасним принципам нейродидактики в аспекті ефективності освітнього процесу. Так, зокрема, використання веб-квестів сприяє підвищенню мотивації та інтенсифікації вивчення іноземної мови, надає освітньому процесу інноваційних характеристик, сприяє результативній самостійній і груповій роботі, ефективно підтримує роботу викладача, надає освітньому процесу пізнавального та ігрового характеру, сприяє усуненню мовних та психологічних «бар'єрів».

Веб-квести відповідають також навчальному принципу Learning by Doing («навчання через практичну діяльність»), відповідно до якого наш головний мозок функціонує так, що ми найкраще сприймаємо та запам'ятовуємо той інформаційний матеріал, який самі опрацьовуємо або виробляємо.

Отже, використання веб-квестів надає заняттю комунікативно-діяльнісного спрямування, креативності, а також відповідає принципам «багатоканального» навчання. Така форма роботи на заняттях найчастіше супроводжується позитивними емоціями i показниками навчального успіху, що $є$, без сумніву, передумовами мотивації та ефективної комунікації на заняттях з іноземної мови.

Ми виділили на прикладі та проаналізували основні етапи роботи над веб-квестом: введення теми, постановка завдання, представлення допоміжних матеріалів, виконання завдання, презентація, обговорення та оцінювання презентацій.

Інтерактивними та інноваційними сервісами для презентації веб-квестів, окрім презентації PowerPoint, у статті названі також мультимедійні програмні засоби Voicethread, Padlet, Spicynodes / Mindmap. Більш розлогий опис та аналіз використання даних ресурсів Веб 2.0 на заняттях з іноземної мови може стати темою майбутніх розвідок.

Проте, безперечно, передумовою оптимального використання Веб 2.0 в навчальній аудиторії $\epsilon$ ретельно продуманий план заняття. Важливим $\epsilon$ не лише бездоганне 
функціонування суто технічних аспектів, а більшою мірою методично-дидактична доцільність використання того чи іншого ресурсу.

Перспективним напрямком подальших розвідок ми вбачаємо також у доцільному використанні на заняттях 3 іноземної мови соціальних мереж, форумів, блогів, кооперативних навчальних проектів, а також інших ресурсів сервісу Веб 2.0 (Etherpad, Padlet, Wordle, Podcast та інших) з метою підвищення мотивації студентів до вивчення іноземних мов.

\title{
ПОДЯКА
}

Наша щира подяка адресується Goethe-Institut в Україні, особливо колишньому референту відділу «Педагогічна кооперація 3 німецької мови» пану Вальтеру Дегену за організацію та проведення численних заходів з підвищення кваліфікації викладачів німецької мови, інформаційне наповнення яких слугувало матеріалом та імпульсом для написання цієї статті.

\section{СПИСОК ВИКОРИСТАНИХ ДЖЕРЕЛ}

[1] Т. О’Рейли «Что такое Веб 2.0.», Компьютерра online, 2005. [Електронний ресурс]. Доступно: http://www.computerra.ru/think/234100/. Дата звернення: Трав. 05, 2018.

[2] M. Spitzer „Lernen - Die Entdeckung des Selbstverständlichen“, Ein Vortrag von Manfred Spitzer auf DVD, 2006.

[3] M. Spitzer „Lernen - Gehirnforschung und die Schule des Lebens“, Spektrum, Heidelberg, 2009, S. 36-77.

[4] M. Spitzer „Medizin für die Bildung - Ein Weg aus der Krise“, Spektrum, Heidelberg, 2010, S. 45-87.

[5] S. Ballweg, S. Drumm u.a. „Wie lernt man die Fremdsprache Deutsch?“, DLL 2, München: KlettLangenscheidt, 2013, S. 56.

Матеріал надійшов до редакиї 14.05.2018 p.

\section{ИСПОЛЬЗОВАНИЕ ВЕБ-КВЕСТОВ В ИЗУЧЕНИИ НЕМЕЦКОГО ЯЗЫКА В УЧРЕЖДЕНИЯХ ВЫСШЕГО ОБРАЗОВАНИЯ}

\author{
Федоренко Лариса Александровна \\ кандидат филологических наук, доцент \\ Житомирский государственный университет имени Ивана Франко, г. Житомир, Украина \\ ORCID ID 0000-0001-5278-7034 \\ fvm34@outlook.com
}

\begin{abstract}
Аннотация. В статье рассмотрено и описано использование веб-квестов как сервиса Веб 2.0 на занятиях по иностранному языку. Проанализированы основные этапы работы над веб-квестом: введение темы, постановка задания, представление вспомогательных материалов, выполнение задания, презентация, обсуждение и оценивание презентаций. Выделены основные качества сервиса: доступность, легкость в использовании, возможность коммуникации и кооперации, в том числе дистанционной, использование коллективного «разума», возможность создания и сохранения информации, визуализация учебного содержания, создание условий для самообразования и саморазвития студентов. В основе исследования лежат концепции, подходы, принципы и методы нейродидактики. В статье указывается, что рациональное использование вебквестов, как и других ресурсов Веб 2.0, на занятиях по иностранному языку вполне соответствует современным принципам нейродидактики в аспекте эффективности учебного процесса, в частности: использование веб-квестов способствует повышению мотивации и интенсификации изучения иностранного языка; придает занятию инновационных характеристик, коммуникативнодеятельного направления, а также креативности, познавательного и игрового характера; эффективно поддерживает работу преподавателя, способствует результативной самостоятельной и групповой работе; соответствует принципам «многоканального» обучения, в которое вовлечено значительное количество органов чувств человека; способствует устранению языковых и психологических «барьеров»; чаще всего сопровождается позитивными эмоциями и показателями
\end{abstract}


учебной успешности, что является предпосылками мотивации и эффективной коммуникации на занятиях иностранного языка. Использование веб-квестов соответствует также принципу «Learning by Doing» («обучение через практическую деятельность»), согласно которому наш головной мозг функционирует таким образом, что мы эффективнее всего воспринимаем и запоминаем тот информационный материал, который сами обрабатываем или вырабатываем. Важно также учитывать индивидуальный темп обучения студентов и возможность привлечения всех учебных типов в соответствии с каналом получения информации: аудитивного, визуального, коммуникативного, моторно-кинестетического.

Ключевые слова: Веб 2.0; Webquest; веб-квест; инновационность; нейродидактика; креативность; PowerPoint.

\title{
USING OF THE WEBQUESTS IN LEARNING GERMAN IN HIGHER EDUCATION ESTABLISHMENTS
}

\author{
Larysa O. Fedorenko \\ PhD of Philological Sciences, Associate Professor \\ Zhytomyr Ivan Franko State University, Zhytomyr, Ukraine \\ ORCID ID 0000-0001-5278-7034 \\ fvm34@outlook.com
}

\begin{abstract}
The article highlights and describes the use of the webquests for Web 2.0 services in foreign language learning. The main stages of the work on the webquests are analyzed: the introduction of the topic, the setting of the task, the presentation of auxiliary materials, the assignment, the presentation, discussion and evaluation of the presentations. The main qualities of the service are identified: accessibility, ease of use, the possibility of communication and cooperation, including distance learning, the use of collective "mind", the possibility of creating and preserving information, visualizing the educational content, creating conditions for self-education and self-development of students. The research is based on the concepts, approaches, principles and methods of the neurodidactics. The article points out that the rational use of the webquests, as well as other Web 2.0 resources, in foreign language classes fully corresponds to the modern principles of the neurodidactics in the course of the effectiveness of the educational process, in particular: the use of the webquests contributes to increasing the motivation and intensification of learning a foreign language; gives attention to the employment of innovative characteristics, communicative activity, as well as creativity, cognitive and playful character; effectively supports the work of the teacher, promotes effective independent and group work; corresponds to the principles of "multi-channel" training; helps to eliminate language and psychological "barriers"; most often accompanied by positive emotions and indicators of academic success, which are prerequisites for motivation and effective communication in the classroom of a foreign language. The use of the webquests also corresponds to the principle of Learning by Doing, according to which our brain functions in such a way that we most effectively perceive and remember the information material that we process or develop.
\end{abstract}

Keywords: Web 2.0; Webquest; innovativeness; neurodidactics; creativity; PowerPoint.

\section{REFERENCES (TRANSLATED AND TRANSLITERATED)}

[1] T. O'Reilly „Chto takoe Veb 2.0“, Kompyuterra online, 2005. [online]. Available: http://www.computerra.ru/think/234100/. Accessed on: May. 05, 2018 (in Russian).

[2] M. Spitzer „Lernen - Die Entdeckung des Selbstverständlichen“, Ein Vortrag von Manfred Spitzer auf DVD, 2006 (in German).

[3] M. Spitzer „Lernen - Gehirnforschung und die Schule des Lebens“, Spektrum, Heidelberg, 2009, S. 36-77 (in German).

[4] M. Spitzer „Medizin für die Bildung - Ein Weg aus der Krise“, Spektrum, Heidelberg, 2010, S. 45-87 (in German).

[5] S. Ballweg, S. Drumm u.a. „Wie lernt man die Fremdsprache Deutsch?“, DLL 2, München: KlettLangenscheidt, 2013, S. 56 (in German).

\section{(cc) BY-NC-SA}

This work is licensed under Creative Commons Attribution-NonCommercial-ShareAlike 4.0 International License. 